\title{
ANALISIS KEMAMPUAN BERPIKIR KRITIS DALAM PEMECAHAN MASALAH MATEMATIKA
}

\author{
Isnaeni Fatmawati ${ }^{*}$, Prasetyo Budi Darmono ${ }^{1)}$, Riawan Yudi Purwoko') \\ 1) Universitas Muhammadiyah Purworejo, Jln K.H. Ahmad Dahlan 3 Purworejo 54111, (0275) 321494 \\ Email: isnaenyfatmawati25@gmail.com
}

\begin{abstract}
Critical thinking ability is essential for the future of students, bearing in mind that it used to prepare students for the many challenges that will arise in their lives, careers, and at the level of their obligations and responsibilities. Critical thinking ability is crucial for students to master so that students are more skilled in preparing an argument, checking the credibility of a source, or making a decision. Critical thinking ability is an essential component that students must-have, especially in the process of learning mathematics. That student can create or formulate, identify, interpret, and plan problem-solving. Critical thinking is a high-level ability to think in terms of analyzing, managing strategies, evaluating, building a logical and clear argument, and drawing conclusions in solving a problem. This research is qualitative research with a phenomenological approach. The purpose of this study is to describe the students' critical thinking skills in solving mathematical problems in the material of the Two-Variable Linear Equation System (SPLDV). The subjects of this study were students of class VIII (eight) who had high mathematical abilities at one of the public Junior High Schools in Purworejo. Based on the results of research and discussion, students' critical thinking ability in solving mathematics problems of junior high school students who have top mathematical skills have been able to achieve all the indicators of critical thinking.
\end{abstract}

Keyword: Critical thinking ability, problem-solving, junior high school, Mathematic

\begin{abstract}
Abstrak
Kemampuan berpikir kritis penting bagi masa depan siswa, mengingat bahwa itu digunakan untuk mempersiapkan siswa dalam menghadapi banyak tantangan yang akan muncul dalam hidup mereka, karir dan pada tingkat kewajiban dan tanggung jawab pribadi mereka. Kemampuan berpikir kritis sangat penting untuk dikuasai siswa agar siswa lebih terampil dalam menyusun sebuah argumen, memeriksa kredibilitas sumber atau membuat keputusan. Kemampuan berpikir kritis merupakan komponen penting yang harus dimiliki siswa terutama dalam proses pembelajaran matematika. Hal ini dimaksudkan supaya siswa mampu membuat atau merumuskan, mengidentifikasi, menafsirkan dan merencanakan pemecahan masalah. berpikir kritis adalah suatu kemampuan berpikir tingkat tinggi dalam hal menganalisis, mengatur strategi, mengevaluasi, membangun sebuah argumen yang logis dan jelas, serta menarik suatu kesimpulan dalam memecahkan suatu permasalahan. Penelitian ini merupakan penelitian kualitatif dengan pendekatan fenomenologi. Tujuan dari penelitian ini yaitu untuk mendeskripsikan kemampuan berpikir kritis siswa dalam pemecahan masalah matematika pada materi Sistem Persamaan Linier Dua Variabel (SPLDV). Subjek penelitian ini adalah siswa kelas VIII yang memiliki kemampuan matematika tinggi di salah satu SMPN di Purworejo. Berdasarkan hasil penelitian dan pembahasan, kemampuan berpikir kritis siswa dalam pemecahan masalah matematika siswa SMP yang memiliki kemampuan matematika tinggi sudah mampu mencapai semua indikator berpikir kritis.
\end{abstract}

Kata Kunci: Kemampuan berpikir kritis, pemecahan masalah, SMP, matematika 


\section{PENDAHULUAN}

Matematika merupakan ilmu dasar bagi ilmu-ilmu yang lain dan mempunyai peranan penting dalam kehidupan sehari-hari. Melihat betapa pentingnya peranan matematika dalam kehidupan manusia, maka matematika sudah dipelajari dari jenjang sekolah dasar hingga perguruan tinggi. Hal ini bertujuan untuk membekali kemampuan berpikir dan bekerjasama siswa yang sangat dibutuhkan. Matematika pada dasarnya merupakan ilmu yang sistematis dan terstruktur sehingga dapat mengembangkan sikap berpikir kritis. Hal ini sesuai dengan standar isi mata pelajaran matematika dalam Peraturan Menteri Pendidikan Nasional Nomor 22 Tahun 2006, macam-macam kemampuan berpikir yaitu kemampuan berpikir logis, analitis, sistematis, kritis dan kreatif. Meskipun telah disebutkan bahwa matematika mampu membekali siswa dengan kemampuan berpikir kritis, tetapi pada kenyataannya kemampuan berpikir kritis siswa SMP di Indonesia masih rendah. Hal ini sesuai dengan beberapa kali laporan studi empat tahunan International Trends in International Mathematics and Science Study (TIMSS) yang dilakukan kepada siswa SMP dengan karakteristik soal-soal level kognitif tinggi yang dapat mengukur kemampuan berpikir kritis siswa menunjukkan bahwa siswa-siswa Indonesia secara konsisten terpuruk di peringkat bawah (Karim, 2015). Hasil tersebut sejalan dengan survey yang dilakukan Programme for International Student Assesment (PISA) tentang kemampuan literasi dimana kemampuan matematika termasuk didalamnya yang dilaksanakan pada tahun 2015 masih berada pada 10 besar peringkat terbawah yaitu peringkat 62 dari 72 negara dengan rata-rata skor 395 .

Menurut Solso dalam Suharna (2018: 14) berpikir didefinisikan sebagai proses menghasilkan representasi mental baru melalui transformasi informasi yang melibatkan interaksi secara kompleks antar logika, abstrak, imajinasi dan pemecahan masalah. Krulik dalam Suharna (2018: 15) membagi tahapan berpikir menjadi empat kategori yaitu: (1) mengingat (recall thinking), (2) berpikir dasar (basic thinking), (3) berpikir kritis (critical thinking), (4) berpikir kreatif (creative thinking). Berdasarkan tahapan berpikir menurut krulik tersebut dapat dilihat berpikir kritis merupakan kemampuan berpikir tingkat tinggi. Kemampuan berpikir kritis sangat penting untuk dikuasai siswa agar siswa lebih terampil dalam menyusun sebuah argumen, memeriksa kredibilitas sumber atau membuat keputusan. Hal ini sependapat dengan Hasibuan \& Surya (2016) yang berpendapat bahwa kemampuan berpikir kritis merupakan dasar untuk menganalisis argumen dan dapat mengembangkan pola pikir secara logis. Ketika siswa memiliki kemampuan berpikir kritis maka siswa tersebut tidak begitu saja percaya dengan apa yang dikatakan guru atau teman-temannya. Selain itu, siswa yang mampu berpikir kritis juga berani berpikir dan mempertanyakan argumentasi guru dan teman-temannya. Suherman et al. dalam Early \& Winarti (2018) menyebutkan bahwa dua hal penting yang merupakan bagian dari tujuan pembelajaran matematika adalah pembentukan sifat yakni pola berpikir kritis dan kreatif. Hal ini dimaksudkan supaya siswa mampu membuat atau merumuskan, mengidentifikasi, menafsirkan dan merencanakan pemecahan masalah.

Berpikir kritis adalah keterampilan berpikir yang dapat dikembangkan melalui pembelajaran dan penilaian di kelas (Widana et al., 2018). Menurut Susanto (2013) mengungkapkan bahwa berpikir kritis adalah suatu kegiatan melalui cara berpikir tentang ide atau gagasan yang berhubung dengan konsep yang diberikan atau masalah yang dipaparkan. Berdasarkan pendapat beberapa ahli maka dapat simpukan bahwa berpikir kritis adalah suatu kemampuan berpikir tingkat tinggi dalam hal menganalisis, mengatur strategi, mengevaluasi, membangun sebuah argumen yang logis dan jelas, serta menarik suatu kesimpulan dalam memecahkan suatu permasalahan.

Materi matematika dan keterampilan berpikir kritis merupakan dua hal yang yang saling berkaitan erat, Hal ini dikarenakan dalam memahami materi matematika diperlukan kemampuan berpikir kritis. Oleh karena itu, kemampuan berpikir kritis dalam pembelajaran 
matematika atau kemampuan berpikir kritis matematis adalah kemampuan yang seharusnya dimiliki oleh setiap siswa untuk memecahkan masalah matematika tak terkecuali siswa sekolah Menengah Pertama (SMP), Mahmuzah dalam Samosir (2019). Pemecahan masalah dalam pembelajaran matematika menjadi bagian yang esensial (inti), karena menyelesaikan gagasan yang menjadi objek-objek pembahasan dalam pembelajaran matematika dengan pemecahan masalah. Jayanti, dkk (2018) berpendapat bahwa pemecahan masalah merupakan hal yang harus diterapkan dalam kegiatan pembelajaran sehingga siswa mampu menyelesaikan masalah yang dihadapi dalam pembelajaran maupun kehidupan sehari-hari. Pemecahan masalah matematis berperan penting untuk menentukan solusi dalam persoalan suatu pokok pembahasan matematika dalam proses pembelajaran matematika. Proses pembelajaran matematika tanpa pemecahan masalah matematis akan mengakibatkan kesenjangan pemahaman dalam proses belajar, karena untuk menyelesaikan suatu persoalan dibutuhkan pemecahan masalah dari setiap yang dipelajari dalam proses pembelajaran matematika. Namun sering sekali terjadi ketika siswa SMP diberikan soal yang berbeda dengan contoh, mereka mengalami kesulitan dalam menyelesaikan soal yang diberikan guru tersebut. Selain itu, siswa juga masih belum bisa memberikan argumennya mengenai jawaban yang sudah diberikan. Hal ini menunjukkan bahwa kemampuan berpikir kritis siswa dalam pemecahan masalah matematika sangat diperlukan.

Berdasarkan hal tersebut peneliti tertarik untuk melakukan penelitian terkait kemampuan berpikir kritis. Penelitian yang akan peneliti lakukan hanya terfokus pada kemampuan berpikir kritis siswa dalam pemecahan masalah matematika. Penelitian ini bertujuan untuk mendeskripsikan kemampuan berpikir kritis siswa dalam pemecahan masalah matematika.

\section{METODE}

Metode yang digunakan dalam penelitian ini adalah penelitian kualitatif dengan pendekatan fenomenologi. Menurut Moleong (2017) fenomenologi merupakan pandangan berpikir yang menekankan pada fokus kepada pengalaman-pengalaman subjektif manusia dan interpretasi-interpretasi dunia. Penelitian fenomenologi dalam penelitian ini digunakan untuk memperoleh gambaran umum tentang kemampuan berpikir kritis siswa SMP dalam pemecahan masalah matematika. Karena kemampuan berpikir kritis dipandang sebagai suatu fenomena dan setiap siswa punya karakteristik yang berbeda. Subjek dalam penelitian ini adalah siswa SMP kelas VIII di salah satu sekolah di kabupaten Purworejo. Teknik pengambilan subjek yang digunakan peneliti dalam penelitian ini yaitu teknik purposive. Sugiyono (2011) berpendapat bahwa teknik purposive adalah teknik pengambilan sampel dengan pertimbangan tertentu.

Data yang di analisis dalam penelitian ini adalah data hasil tes pemecahan masalah SPLDV dan hasil wawancara untuk mendeskripsikan kemampuan berpikir kritis siswa dalam pemecahan masalah matematika. Analisis data dalam penelitian ini mengacu pada analisis data model Miles \& Huberman. Menurut Miles \& Huberman (Sugiyono, 2011) aktivitas dalam analisis data kualitatif dilakukan secara interaktif dan berlangsung secara terus menerus sampai tuntas, sehingga datanya sudah jenuh. Aktivitas yang dimaksud dalam penelitian kualitatif yaitu mereduksi data, penyajian data, dan penarikan kesimpulan / verifikasi. Instrumen yang digunakan dalam penelitian ini berupa instrumen soal tes kemampuan berpikir kritis. Soal yang di berikan merupakan soal pemecahan masalah matematika dengan tipe soal non rutin yang memuat indikator kemampuan berpiki kritis. Adapun indikator kemampuan berpikir kritis yang akan di analisis dapat dilihat pada Tabel 1. 
Tabel 1.Indikator Kemampuan Berpikir Kritis

\begin{tabular}{|c|c|c|}
\hline No & $\begin{array}{c}\text { Indikator Kemampuan Berpikir } \\
\text { Kritis }\end{array}$ & $\begin{array}{c}\text { Sub Indikator Kemampuan Berpikir } \\
\text { Kritis }\end{array}$ \\
\hline 1. & $\begin{array}{l}\text { Mampu menganalisis } \\
\text { permasalahan }\end{array}$ & $\begin{array}{l}\text { siswa mampu menentukan ide pokok } \\
\text { permasalahan, menyusun apa yang } \\
\text { diketahui dan ditanyakan. }\end{array}$ \\
\hline 2. & $\begin{array}{l}\text { Mampu mengatur strategi pemecahan } \\
\text { masalah }\end{array}$ & $\begin{array}{l}\text { siswa mampu menentukan solusi } \\
\text { pemecahan masalah. }\end{array}$ \\
\hline 3. & $\begin{array}{l}\text { Mampu mengevaluasi dan memberikan } \\
\text { argumen yang logis terhadap suatu } \\
\text { pernyataan }\end{array}$ & $\begin{array}{l}\text { siswa mampu membenarkan atau } \\
\text { menyalahkan sebuah pernyataan dan } \\
\text { memberikan argumen yang logis. }\end{array}$ \\
\hline 4. & Menarik kesimpulan & $\begin{array}{l}\text { siswa mampu memberikan kesimpulan } \\
\text { atas hasil jawaban yang diberikan. }\end{array}$ \\
\hline
\end{tabular}

\section{HASIL DAN PEMBAHASAN}

Hasil penelitian dalam penelitian ini berupa hasil tes tertulis, hasil wawancara, catatan lapangan (berdasarkan video proses pengerjaan subjek), dan dokumentasi. Tes yang digunakan terdiri dari satu soal bertingkat dengan materi Sistem Persamaan Linear Dua Variabel (SPLDV) sedangkan wawancara dilakukan setelah subjek mengejakan soal tes kemampuan berpikir kritis. Untuk memperoleh data dalam penelitian digunakan tes kemampuan perpikir kritis dengan tipe soal pemecahan masalah matematika tidak rutin dapat dilihat pada Gambar 1.

Bu Maya dan Pak Ardian sedang menyiapkan hadiah untuk lomba perayaan hari kemerdekaan dengan membeli hadiah di toko perlengkapan sekolah. Di toko A, $\mathrm{Bu}$ Maya membeli 5 pack buku tulis dan 5 tas sekolah dengan harga Rp. 550.000,00, sedangkan pak Ardian membeli 10 pack buku tulis dan 2 tas sekolah dengan harga Rp. 460.000,00. Karena masih kekurangan, bu Maya membeli lagi di toko B 10 pack buku tulis dan 3 tas sekolah dengan membayar Rp. 460.000,00 dan pak Ardian membeli lagi 5 pack buku tulis dan 2 tas sekolah dengan harga Rp. $265.000,00$.

Pertanyaan:

a. Apa informasi yang kamu peroleh dari soal diatas?

b. Jika ibu Maya membeli empat pack buku dan dua tas sekolah lagi di toko A. Berapakah uang yang harus dibayarkan oleh ibu Maya?

c. Apakah harga satu tas sekolah di toko B lebih mahal dari harga 3 pack buku tulis di toko A? Berikan alasan dan kesimpulan kamu.

Gambar 1. Soal Pemecahan Masalah tidak rutin

Berdasarkan hasil anaisis data yang dilakukan pada $\mathrm{S}_{1}, \mathrm{~S}_{2}, \mathrm{~S}_{3}$, dan $\mathrm{S}_{4}$ dengan kategori memiliki kemampuan matematika tinggi berdasarkan nilai Penilaian Harian (PH) pada materi Sistem Persamaan Linear Dua Variabel (SPLDV) dan pertimbangan dari guru mata pelajaran matematika. Menunjukkan bahwa secara umum keempat subjek telah memenuhi keempat indicator kemampuan berpikir kritis. Berikut akan disajikan lebih lanjut tentang kemampuan berpikir kritis siswa dalam pemecahan masalah matematika berdasarkan hasil tes kemampuan berpikir kritis, hasil wawancara, dan catatan lapangan berdasarkan indikator berpikir kritis yaitu (1) mampu menganalisis suatu permasalahan, (2) mampu mengatur strategi pemecahan 
masalah, (3) mampu mengevauasi dan memberikan argumen yang logis terhadap suatu penyataan, dan (4) menarik kesimpulan.

\section{Analisis Indikator Mampu Menganalisis Suatu Permasalahan}

Berpikir kritis pada indikator mampu menganalisis suatu permasalahan, dapat dilihat dari subjek mampu memberikan informasi kembali mengenai apa yang diketahui dan ditanyakan berdasarkan permasalahan yang terdapat pada soal pemecahan masalah yang diberikan. Kemudian pada saat wawancara, subjek dapat menjelaskan keterkaitan antara yang diketahui dengan yang ditanyakan. Selain itu subjek juga sudah mampu menyajikan kembali informasi dari soal cerita dalam bentuk kelompok. Meskipun ada beberapa informasi yang tidak dituliskan, namun ketika tahap wawancara dapat melengkapi dan memberi alasan dengan tepat. Hal ini sependapat dengan Adinda (Azizah, dkk. 2018) orang yang mampu berpikir kritis adalah orang yang mampu menyimpulkan apa yang diketahuinya, mengetahui cara menggunakan informasi untuk memecahkan permasalahan, dan mampu mencari sumbersumber informasi yang relevan sebagai pendukung pemecahan masalah.

\section{Analisis Indikator Mampu Mengatur Strategi Pemecahan Masalah}

Pada tahap ini ditunjukkan dengan subjek mampu menentukan solusi pemecahan masalahnya. Subjek mampu menentukan solusi pemecahan masalahnya dapat dilihat saat subjek memilih alternatif penyelesaian yang akan digunakan. Pada saat menentukan metode tersebut subjek sedang melakukan berpikir kritis berupa menentukan strategi untuk memecahkan masalah Sistem Persamaan Linear Dua Variabel (SPLDV). Hal ini sesuai dengan pendapat Anwar dan Amin (2013) pada tahap melaksanakan rencana dalam menyelesaikan masalah siswa akan mengerjakan soal dengan mengacu pada rencana yang telah disusun. Keempat subjek mampu menjawab dengan benar dan sesuai dengan apa yang tertera pada soal. Dalam hal ini dapat dilihat dari siswa mampu mencari harga satu pack buku tulis serta harga satu tas sekolah di toko A dan toko B. Selain itu pada tahap mampu mengatur strategi juga digunakan untuk mendukung argumen yang akan siswa berikan agar lebih logis.

Berdasarkan hasil analisis data pada tahap mampu mengatur strategi pemecahan masalah, subjek mampu menentukan solusi pemecahan masalah. Hal ini di tunjukkan dengan subjek mampu menjawab dan memecahkan masalah dengan benar sesuai dengan apa yang di tanyakan pada soal.

\section{Analisis Indikator Mampu Mengevaluasi dan Memberikan Argumen Yang Logis Terhadap Suatu Pernyataan.}

Pada tahap ini, siswa harus mampu membenarkan atau menyalahkan sebuah pernyataan dan memberikan argumen yang logis. Menurut Beyer dalam Rasiman (2012) ketika siswa bisa dalam mengambil keputusan yang tepat untuk memutuskan suatu argumen dan memberikan alasan yang tepat dan jelas dari suatu argumen tersebut, maka siswa menggunakan proses berpikir kritis. Maka dalam hal ini kemampuan berpikir kritis subjek dapat dilihat ketika subjek mampu membuat keputusan bahwa pernyataan pada soal (c) itu salah dan di sertai dengan argumen yang logis. Berdasarkan penjelasan tersebut maka dapat disimpulkan bahwa subjek $S_{1}$ memenuhi indikator tahap mampu mengevaluasi dan memberikan argumen yang logis terhadap suatu pernyataan.

\section{Analisis Indikator Menarik Kesimpulan}

Kemampuan berpikir subjek dapat dilihat dari aktivitas subjek saat memberikan kesimpulan atas hasil perhitungan yang sudah dilakukan. Subjek memberikan kesimpulan akhir atas jawaban yang diberikan dengan jelas dan logis. Hal ini sesuai dengan pendapat 
Indraningtias \& Wijaya dalam (Azizah, Sulianto, \& Cintang, 2018) Siswa yang kritis cenderung lebih aktif dalam usaha menyelesaikan masalah, salah satu keaktifannya yaitu mampu menarik kesimpulan dari penyelesaian matematis yang ada.

\section{KESIMPULAN}

Berpikir kritis yang dilakukan siswa pada indikator mampu menganalisis permasalahan dapat dilihat dari siswa dapat memberikan informasi kembali mengenai apa yang diketahui dan ditanyakan pada soal. Selain itu siswa juga sudah mampu memberi argumen mengenai keterkaitan antara apa yang diketahui dengan apa yang ditanyakan berdasarkan informasi yang telah diperoleh. Pada indikator mampu mengatur strategi dalam pemecahan masalah siswa melakukan berpikir kritis berupa mencari alternatif untuk memecahkan masalah Sistem Persamaan Linear Dua Variabel (SPLDV).alternatif yang siswa lakukan yaitu dengan mencari nilai $x$ dan $y$ terlebih dahulu. Pada indikator selanjutnya yaitu siswa mampu mengevaluasi dan memberikan argumen yang logis terhadap suatu pernyataan, skemampuan berpikir kritis siswa berupa mampu membuat keputusan bahwa pernyataan pada soal (c) itu salah dan di sertai dengan argumen yang logis. Pada indikator terakhir siswa mampu menarik kesimpulan, siswa berpikir kritis berupa siswa mampu memberikan penjelasan dan kesimpulan secara jelas dan logis berdasarkan hasil penyelidikan yang telah dilakukan.

\section{DAFTAR PUSTAKA}

Anwar, S dan Amir, S. M. 2013. Penggunaan Langkah Pemecahan Masalah Polya Dalam Menyelesaikan Soal Cerita Pada Perbandingan di Kelas VI MI Al-Ibrohim Galis Bangkalan. Jurnal Pendidikan Matematika e-Pensa. Vol.1, No. 1, hlm. 1-6.

Azizah, M., Sulistianto, J., Cintang, N. 2018. Analisis Kemampuan Berpikir Kritis Siswa Sekolah Dasar Pada Pembelajaran Matematika Kurikulum 2013. Jurnal Penelitian Pendidikan, Vol. 6, No. 1.

Depdiknas. 2006. Peraturan Menteri Pendidikan Nasional No. 22 Tahun 2006 tentang Standar Isi untuk Satuan Pendidikan Dasar dan Menengah. Jakarta: Depdiknas.

Early, O. A., \& Winarti, E. R. (2018). Analisis Kemampuan Berpikir Kritis Matematis Ditinjau Dari Kemandirian Siswa Kelas VIII Melalui Pembelajaran Model PBL Pendekatan Saintifik Berbantuan Fun Pict. Prisma Unnes, 1, 388-399.

Hasibuan, S. H \& Surya. E. 2016. Analysis Of Critical Thinking Skills Class X Smk Patronage State North Sumatra Province Academic Year 2015/2016. (Jurnal Saung Guru: Vol. VIII No.2 April (2016))

Moleong. 2017. Metodologi Penelitian Kualitatif. Bandung: PT Remaja Rosdakarya.

Rasiman. 2012. Penelurusan Proses Berpikir Kritis Dalam Menyelesaikan Masalah Matematika Bagi Siswa Dengann Kemampuan Matematika Tinggi. Jurnal Pendidikan Matematika, Vol. 3, No. 1.

Sugiyono. 2011. Metode Penelitian Kuantitatif Kulitatif Dan R\&D. Bandung: Alfabeta.

Susanto, A. 2013. Teori Belajar dan Pembelajaran di Sekolah Dasar. Jakarta: Prenadamedia Group.

Widana, I. W., Yoga, I. M., Nyoman, N., Agung, I. G., \& Jayantika, T. (2018). Higher Order Thinking Skills Assessment towards Critical Thinking on Mathematics Lesson. JSSH, 2(1), 24-32. https://doi.org/10.29332/ijssh.v2n1.74 